\title{
O compromisso com a divulgação do conhecimento científico
}

\author{
The commitment to the dissemination of scientific knowledge
}

\author{
Daniel Almeida Marinho ${ }^{1,2^{*}}$
}

Assistimos, nestes últimos anos, a um crescimento sustentado da revista Motricidade, alicerçado no contributo de todos, especialmente dos nossos leitores e dos autores dos artigos científicos, que conjuntamente com a equipa editorial permitiram trazer a Motricidade para um patamar difícil de prever anteriormente. Esta situação tem como consequência uma exigência cada vez maior, o que eleva a responsabilidade de todos na procura de um "produto" de qualidade também superior.

É com muito agrado que verificamos o incremento do número de submissões, bem como a diversidade dos temas em análise dos vários artigos submetidos, indicando a penetração em áreas afins das Ciências do Desporto.

Face ao elevado volume de submissão de artigos, há a tentação de apresentar valores de rejeição elevados, procurando com isso mostrar a qualidade de uma revista. Obviamente que aumentando a procura, e não aumentando a oferta na mesma proporção, é necessário fazer uma seleção muito mais criteriosa para decidir quem tem o direito a ver o seu artigo publicado. Contudo, no nosso entender, esta opção é extremamente arriscada se não for executada com equidade. Argumentos como o número reduzido de elementos que constituem a amostra do estudo, ou a apresentação de estudos correlacionais/descritivos, habitualmente utilizados para a rejeição imediata dos artigos, podem levar, se não forem associados com outros critérios de avaliação da qualidade dos artigos científicos, a um enviesamento do foco da revista para uma tipologia de estudos em detrimento de outras.

Num momento em que a Ciência em Portugal passa por um período conturbado, em que se argumenta com a mudança de paradigma no apoio à Investigação e Desenvolvimento, a revista Motricidade pode e deve continuar a assumir um papel central na divulgação do conhecimento científico na área das Ciências do Desporto. Uma Ciência em que somente as elites são financiadas, e em que apenas a Ciência associada à rentabilidade financeira de um produto/conhecimento é apoiada, pode levar a um desinvestimento, desmotivação e desinteresse por outras áreas do conhecimento, que, por variadíssimas razões, encontram dificuldades em se associar ao mundo empresarial, mas que nem por isso merecem ser renegadas do panorama científico. Antes pelo contrário, e as Ciências do Desporto são disso um bom exemplo. São vários os exemplos de projetos bem estruturados, com temas atuais e relevantes, e com suporte científico a sustentá-los, que viram as suas candidaturas a financiamento serem recusadas, sem que se consiga compreender quais os critérios para essa decisão, que não sejam unicamente critérios economicistas de resultados de curto prazo.

Este desinteresse e desinvestimento pela investigação nalgumas áreas, entre as quais a nossa área de intervenção, deve permitir à Motricidade continuar a assumir um papel de destaque na divulgação da investigação científica, incluindo a difusão da investigação em língua portuguesa.

\footnotetext{
${ }^{1}$ Editor Associado da Revista Motricidade, Universidade da Beira Interior, Covilhã, Portugal

${ }^{2}$ Centro de Investigação em Desporto, Saúde e Desenvolvimento Humano, Vila Real, Portugal

* Autor correspondente: Departamento de Ciências do Desporto, Universidade da Beira Interior, Rua Marquês d'Ávila e Bolama, 6201-001 Covilhã - Portugal; E-mail: dmarinho@ubi.pt
} 


\section{2 | DA Marinho}

Não queremos com isto dizer que a divulgação em língua estrangeira não é importante. Realçamos que é fundamental e deve continuar a ser efetuada. Referimos apenas que a divulgação em língua portuguesa não deve ser descurada, e é compatível com a divulgação em língua estrangeira, como se pode verificar pelos vários idiomas em que é possível escrever os artigos na Motricidade.

Não queremos também dizer que a qualidade dos artigos que são aceites para publicação deve diminuir. Consideramos precisamente o contrário. Mais responsabilidade exige maior exigência por parte de todos os interessados na divulgação do conhecimento científico. Chamamos a atenção que deve haver uma sensibi- lização para artigos em áreas que habitualmente são menos divulgadas em revistas científicas das Ciências do Desporto, como, a título ilustrativo, algumas áreas das ciências sociais e humanas, bem como diferentes tipologias de investigação e diferentes formatos de artigo.

Neste sentido, cada vez mais, a Motricidade deve assumir um papel central na divulgação da ciência, contribuindo para o desenvolvimento e disseminação do conhecimento científico de caráter teórico e empírico nas áreas científicas do desporto, psicologia e desenvolvimento humano, e saúde, adotando sempre que possível uma natureza interdisciplinar, como enunciado nos objetivos da revista. 